\title{
STUDENT'S ABILITY IN SOLVING MATH STORY PROBLEMS: GENDER DIFFERENCES
}

\author{
Ilham Wahyudi \\ SMPN 2 Tigo Lurah, Kabupaten Solok, Sumatera
} Barat, Indonesia

Email: ilhamwahyudi2908@gmail.com

\begin{abstract}
The research aimed at describing students' ability to solve math story problems viewed from a perspective of gender. The research design was descriptive qualitative research with 16 students of the seventh grade of SMPN 2 Tigo Lurah as the sample. The data were gathered through social arithmetic math story problems and analyzed descriptively by following certain procedures like calculating the results, grouping them into low, medium and high categories. The results indicate female students' ability in solving math story problems are better than male students. It is obviously seen from the average scores; 82 versus 75 .
\end{abstract}

\begin{abstract}
Abstrak :Tujuan penelitian ini adalah untuk menggambarkan kemampuan penyelesaian soal cerita matematika siswa ditinjau dari perspektif gender. Jenis penelitian ini adalah penelitian deskriptif kualitatif. Subjek dalam penelitian ini adalah siswa SMPN 2 Tigo Lurah kelas VII semester 2 yang berjumlah 16 orang siswa. Materi bahasan yang digunakan adalah aritmatika sosial. Metode pengumpulan data pada penelitian ini adalah latihan soal. Teknik analisa data dalam penelitian ini adalah dengan melihat hasil latihan soal siswa dalam menyelesaikan soal cerita matematika, kemudian dikelompokkan dalam kategori rendah, sedang, dan tinggi. Hasil penelitian ini menunjukkan bahwa nilai rata-rata siswa laki-laki 82 dan nilai rata-rata siswa perempuan 75. Kesimpulan yang diperoleh dari penelitian ini adalah kemampuan penyelesaian soal cerita siswa laki-laki lebih baik dari pada siswa perempuan.
\end{abstract}




\section{PENDAHULUAN}

Matematika merupakan salah satu mata pelajaran penting dalam dunia pendidikan. Hal ini terbukti dengan dijadikannya matematika sebagai mata pelajaran wajib disetiap tingkat, mulai dari tingkat dasar, menengah dan atas. Matematika menjadi ilmu yang wajib untuk dikuasai, karena penerapannya tidak digunakan pada mata pelajaran matematika saja, tetapi juga digunakan pada pelajaran lain, misalnya Fisika, Ekonomi, Akuntasnsi, dan lain-lain. Selain itu, matematika juga sangat banyak diterapkan dalam kehidupan sehari-hari, seperti menghitung untung rugi pada perdagangan, menentukan sudut pada konstruksi bangunan, statistika pada perkiraan cuaca, dan lain-lain.

Salah satu materi pada mata pelajaran matematika tingkat SMP yang sangat dekat penerapannya dengan kehidupan sehari-hari adalah materi Aritmatika Sosial. Pada kurikulum 2013, materi Aritmatika sosial dipelajari pada kelas 7. Aritmatika sosial adalah materi yang membahas tentang kegiatan yang terkait dengan dunia perekonomian, seperti penjualan, pembelian, untung, rugi, bunga, pajak, dan lain-lain. Salah satu cara yang digunakan agar siswa merasakan pengalaman dalam penerapan matematika dalam materi Aritmatika sosial dalah dengan soal cerita.

Soal cerita matematika merupakan soal matematika yang diberikan dalam bentuk cerita, baik secara lisan maupun tulisan. Soal cerita mengunakan kalimat verbal biasa, yang makna dari konsep dan ungkapannya dapat dinyatakan dalam simbol dan relasi matematika. Menurut Polya, langkah-langkah yang dilakukan oleh siswa untuk menyelesaikan soal cerita matematika adalah: 1) Understanding the problem. Pertama sekali, siswa harus mampu memahami masalah yang ada pada soal. Biasanya pada tahap ini siswa menentukan apa yang diketahui dan apa yang ditanyakan dalam soal, siswa memetakan setiap informasi dan menempatkan setiap unsur pada peran masing-masing, serta membuat catatancatatan kecil atau gambar yang berisi halhal yang akan memudahkan dalam memahami soal dan menyelesaikannya, 2) Devising a plan. Selanjutnya, siswa akan menentukan rencana penyelesaian. Dalam tahap ini siswa akan mengacu pada informasi yang memuat pertanyaan yang ada pada soal, kemudian membuat hubungan dengan informasi yang diketahui. Selanjutnya siswa akan mengubah informasi yang dikumpulkan kedalam sebuah bahasa matematika, dan dari bahasa matematika tersebut akan ditentukan sebuah model matematika yang akan digunakan untuk melakukan penyelesaian soal. 3) Carriying out the plan. Dalam tahap ini siswa akan melaksanakan rencana yang tertulis pada langkah ke dua. Hal paling penting dalam tahapan ini adalah ketelitian siswa dalam menjalankan setiap langkah penyelesaian berdasarkan model matematika yang sudah ditentukan. Setelah setiap langkah pada model matematika tahap kedua dilakukan 
dengan benar, selanjutnya siswa akan melakukan penghitungan pada setiap langkah sehingga akan mendapatkan sebuah hasil akhir sesuai apa yang ditanyakan soal. 4) Looking back. Langkah terakhir adalah memeriksa proses penyelesaian soal dan hasil. Didalam tahapan ini, siswa melakukan kegiatan menarik kesimpulan. Biasanya pada tahap ini memuat kembali informasi mengenai hal yang ditanyakan dalam soal, dan jawaban dari pertanyaan tersebut.

Jika siswa sudah memahami soal cerita, berarti siswa tersebut mengerti sesuatu, seperti mampu mengubah informasi verbal menjadi sebuah bahasa matematika, mampu memilah dan menempatkan sebuah informasi menjadi hal yang diketahui dan ditanya, mampu mengubah kata-kata kedalam simbolsimbol, mampu menentukan sebuah model matematika untuk melakukan penyelesaian, dan sebagainya. Menurut Mardjuki, kemampuan yang diperlukan untuk menyelesaikan soal cerita yaitu: 1) Kemampuan komputasi matematika, seperti penjumlahan, pengurangan, perkalian dan pembagian. 2) Kemampuan bahasa, yaitu kemampuan mengubah bahasa sehari-hari kedalam bahasa matematika. 3) Kemampuan penalaran, yaitu kemampuan menemukan permasalahan dan menentukan penyelesaiannya.

Dari beberapa pendapat sebelumnya, dapat disimpulkan bahwa kemampuan siswa dalam menyelesaikan soal cerita dapat dilihat dari:
1. Pemahaman masalah. Hal ini dapat dilihat dari kemampuan siswa dalam menuliskan apa yang diketahui dan apa yang ditanya dalam suatu soal cerita.

2. Perencanaan. Hal ini dapat dilihat dari kemampuan siswa dalam membuat suatu model matematika berdasarkan sebuah soal cerita.

3. Pelaksanaan rencana. Hal ini dapat dilihat dari kemampuan siswa dalam menyelesaikan model matematika yang sudah disusun.

4. Penarikan kesimpulan. Hal ini dapat dilihat dari kemampuan siswa dalam menyimpulkan jawaban sesuai dengan soal cerita.

Kemampuan penyelesaian soal cerita setiap siswa tentunya berbeda-beda. Ada banyak faktor yang mempengaruhi perbedaan kemampuan tersebut, salah satunya adalah perbedaan jenis kelamin atau gender. Perbedaan gender menyebabkan perbedaan fisiologi dan akan berpengaruh pada perbedaan psikologis siswa dalam proses belajar mengajar. Hal ini menyebabkan siswa laki-laki dan perempuan memiliki perbedaan dalam proses belajar mengajar, termasuk dalam pelajaran matematika. Perbedaan gender atau bias gender dalam dunia pendidikan tentunya berpengaruh pada hasil belajar siswa. Bias gender ini tidak hanya terjadi dan disosialisasikan dalam proses serta sistem pembelajaran di sekolah, tetapi juga terjadi pada pendidikan dalam lingkungan keluarga. 
Pada masa kanak-kanak hingga memasuki pendidikan dasar, jumlah siswa laki-laki dan perempuan berbakat relatif sama, sedangkan saat memasuki usia remaja, jumlah siswa berbakat laki-laki lebih banyak dibandingkan siswa berbakat perempuan. Selanjutnya pada saat memasuki usia dewasa, jumlah siswa berbakat laki-laki dan perempuan menjadi jauh berbeda. Perbedaan gender ini tidak hanya mempengaruhi kemampuan matematika siswa saja, akan tetapi juga akan mempengaruhi cara memperoleh pengetahuan matematika siswa tersebut. Dalam beberapa penelitian diyatakan bahwa pengaruh perbedaan gender ini kepada pembelajaran matematika siswa yaitu disebabkan oleh faktor biologis pada otak anak laki-laki dan perempuan. Siswa perempuan diketahui lebih bagus dalam kemampuan berbahasa dan menulis, sedangkan siswa laki-laki diketahui lebih bagus dalam bidang matematika dan kemampuan ruang.

Berdasarkan uraian diatas, penulis tertarik untuk melakukan sebuah penetian dengan judul "Analisis kemampuan penyelesaian soal cerita matematika ditinjau dari perspektif gender"

\section{METODE}

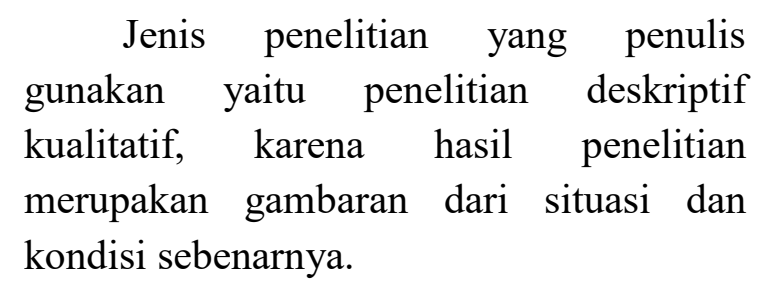

Tujuan penelitian ini adalah untuk mengetahui perbedaan kemampuan penyelesaian soal cerita antara siswa lakilaki dan siswa perempuan. Penelitian ini dilakukan pada siswa kelas VII di Sekolah Menengah Pertama (SMP) Negeri 2 Tigo Lurah, Kabupaten Solok, pada tahun ajaran 2020/2021. Jumlah siswa pada penelitian ini adalah 16 siswa, yang terdiri dari 10 orang siswa laki - laki dan 6 orang siswa perempuan.

Tes kemampuan penyelesaian soal cerita diawali dengan pemberian materi aritmatika sosial, kemudian diakhiri dengan latihan soal berupa 1 buah soal cerita dengan jawaban uraian. Latihan soal tersebut akan dianalisis untuk mengetahui perbedaan kemampuan penyelesaian soal cerita antara siswa laki-laki dan siswa perempuan, dengan melihat nilai rata-rata antara siswa laki-laki dengan siswa perempuan tersebut.

Adapun kategori kemampuan penyelesaian soal cerita siswa dikonversi seperti tabel berikut:

\begin{tabular}{|c|c|}
\hline $\begin{array}{c}\text { Rata-rata nilai } \\
\text { siswa }\end{array}$ & Kategori \\
\hline$<60$ & Rendah \\
\hline $60-80$ & Sedang \\
\hline $80-100$ & Tinggi \\
\hline
\end{tabular}

Tabel 1. Konversi nilai menjadi kemampuan siswa 


\section{HASIL DAN PEMBAHASAN}

Untuk mengetahui kemampuan penyelesaian soal cerita siswa, dapat dilihat dari nilai rata-rata yang diperoleh siswa laki-laki dan siswa perempuan. Nilai tertinggi yang diperoleh siswa laki-laki adalah 95 dan nilai terendah siswa laki-laki adalah 65 , sedangkan nilai tertinggi yang diperoleh siswa perempuan adalah 85 dan nilai terendah siswa perempuan adalah 55 . Nilai rata-rata seluruh siswa dapat dilihat dari tabel berikut:

\begin{tabular}{|c|c|c|}
\hline Gender & $\begin{array}{c}\text { Nilai rata- } \\
\text { rata }\end{array}$ & Kategori \\
\hline Laki-laki & 82 & Tinggi \\
\hline Perempuan & 75 & Sedang \\
\hline
\end{tabular}

Tabel 2. Data nilai rata-rata

Berdasarkan data nilai yang ada pada Tabel 2, dapat dilihat bahwa nilai rata-rata siswa laki-laki adalah 82, sedangkan nilai rata-rata perempuan adalah 75 . Hal ini berarti siswa laki-laki memiliki kemampuan labih baik dalam penyelesaian soal cerita dibandingkan siswa perempuan.

Soal cerita yang diberikan sebagai latihan soal bagi siswa untuk melihat kemampuan penyelesaian soal cerita terlihat pada gambar berikut:

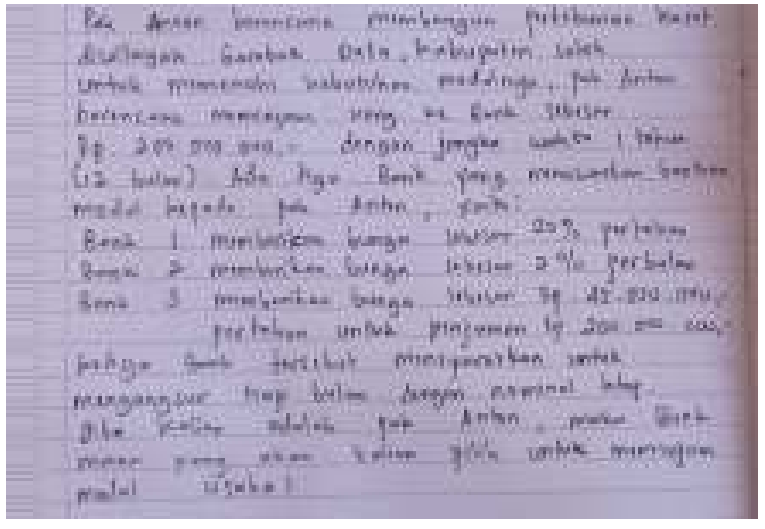

Gambar 1. Naskah soal cerita

Adapun jawaban dari siswa laki-laki dan perempuan dengan nilai tertinggi dan nilai terendah adalah sebagai berikut:

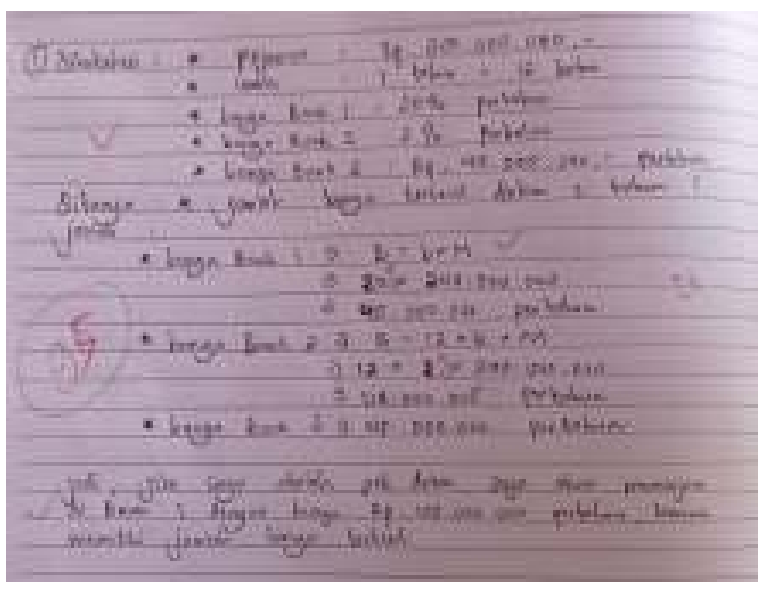

Gambar 2. Jawaban siswa lakilaki dengan nilai tertinggi

Jawaban siswa laki-laki dengan nilai tertinggi bisa dikatakan hampir sempurna. Hanya saja terdapat kekurangan ketelitian dalam menuliskan simbol matematika. Semua indikator kemampuan penyelesaian soal cerita terpenuhi, dan langkah-langkahnya diurutkan dengan baik dan benar, sehingga uraian jawabannya mudah untuk dipahami. 


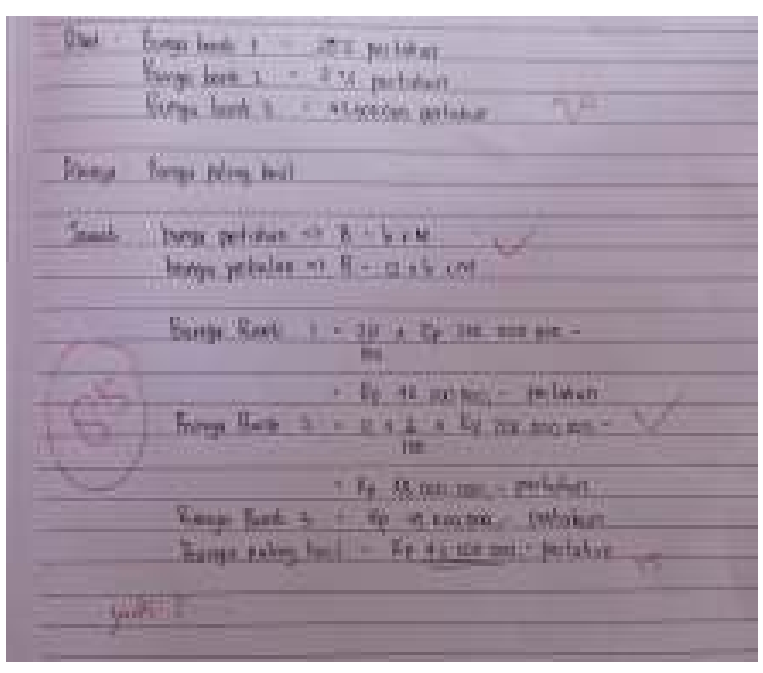

Gambar 3. Jawaban siswa perempuan dengan nilai tertinggi

Jawaban siswa perempuan dengan nilai tertinggi tidak lengkap pada indikator pemahaman masalah dan indicator penarikan kesimpulan. Kekurangan pada indicator pemahaman masalah yaitu ada satu hal diketahui yang seharusnya ditulis pada jawaban, tetapi tidak dituliskan oleh siswa, sedangkan kekurangan pada indicator penarikan keimpulan yaitu tidak adanya kalimat kesimpulan yang ditulis oleh siswa setelah melakukan perhitungan matematika. Akan tetapi pada indicator perencanaan dan pelaksanaan rencana, siswa perempuan dengan nilai tertinggi menjawab dengan sempurna tanpa ada kesalahan.

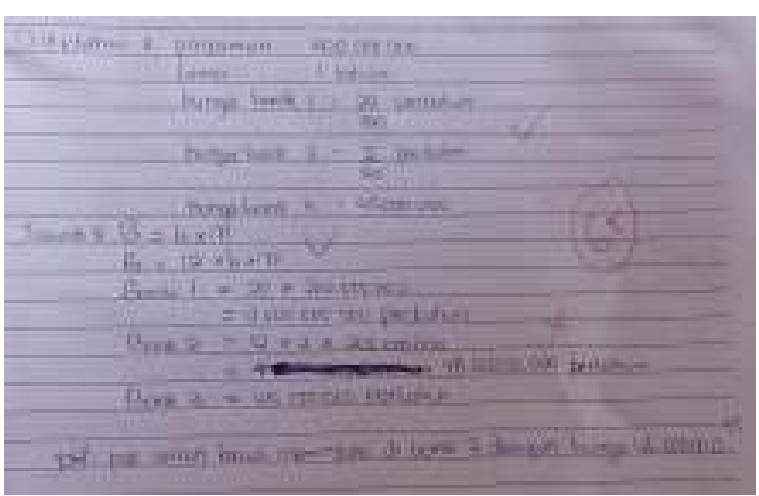

Gambar 4. Jawaban siswa laki-laki dengan nilai terendah

Jawaban siswa laki-laki dengan nilai terendah pada indicator pemahaman masalah sudah menjabarkan semua hal yang diketahui, akan tetapi tidak menuliskan apa yang ditanya. Pada indicator perencanaan, siswa laki-laki dengan nilai terendah juga sudah membuat model matematika yang benar, akan tetapi pada indicator pelaksanaan rencana, siswa laki-laki dengan nilai terendah berkali-kali melakukan kesalahan pada proses penghitungan dan juga penempatan symbol matematika, sehingga hasil akhir yang diperoleh pada jawaban tidak benar. Pada indicator penarikan kesimpulan, siswa laki-laki dengan nilai terendah menuliskan kalimat penarikan kesimpulan, akan tetapi karena jawaban pada proses pelakasanaan rencana salah, penarikan kesimpulan juga menyajikan jawaban yang salah, dan juga penggunaan symbol matematika yang salah juga. 
AGENDA : Analisis Gender dan Anak,Vol. 3 (2), 2021, (Desember)

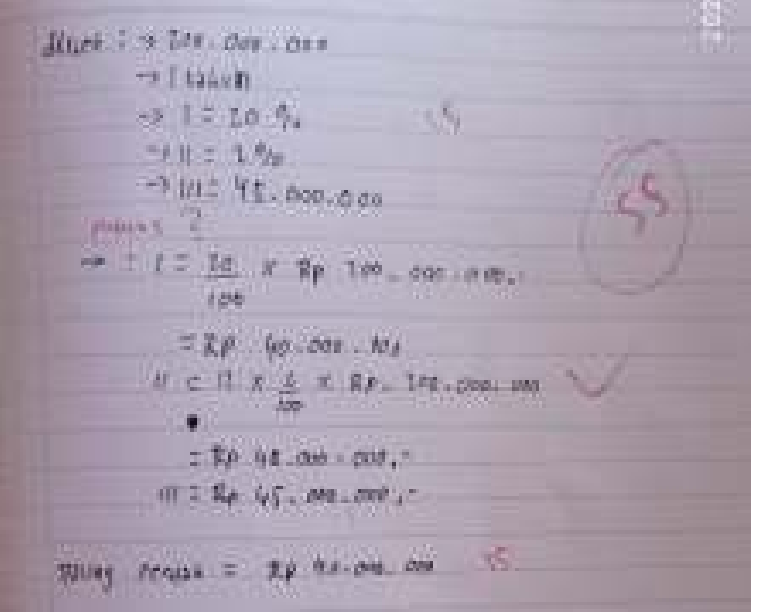

Gambar 5. Jawaban siswa perempuan dengan nilai terendah

Jawaban siswa perempuan dengan nilai terendah pada indicator pemahaman masalah hanya menuliskan angka-angka, tanpa menjelaskan apa yang diketahui dan apa yang ditanya. Pada indicator perencanaan, siswa perempuan dengan nilai terendah juga tidak menyajikan model matematika pada soal tersebut. Akan tetapi pada indicator pelaksanaan rencana, siswa ini dapat menyelesaikan perhitungan model matematika dengan baik dan benar, tanpa ada kesalahan pada penghitungan. Pada indicator penarikan kesimpulan, siswa perempuan dengan nilai terendah menuliskan kalimat kesimpulan, tetapi hanya dengan model matematika saja, tanpa ada penjelasan lebih lanjut.

Untuk melihat nilai rata-rata siswa laki dan perempuan berdasarkan indicator kemampuan penyelesaian soal cerita dapat dilihat pada tabel berikut:

\begin{tabular}{|l|l|l|}
\hline \multirow{2}{*}{ Indikator } & \multicolumn{2}{|c|}{ Rata - rata } \\
\cline { 2 - 3 } & Laki-laki & Perempuan \\
\hline $\begin{array}{l}\text { Pemahaman } \\
\text { masalah }\end{array}$ & 85 & 75 \\
\hline Perencanaan & 85 & 70 \\
\hline $\begin{array}{l}\text { Pelaksanaan } \\
\text { rencana }\end{array}$ & 73 & 85 \\
\hline $\begin{array}{l}\text { Penarikan } \\
\text { kesimpulan }\end{array}$ & 85 & 70 \\
\hline
\end{tabular}

Tabel 3. Rata-rata kemampuan siswa lakilaki dan perempuan berdasarkan indicator

kemampuan penyelesaian soal cerita matematika.

Jika dikategorikan, kemampuan penyelesaian soal cerita siswa laki-laki dan perempuan dapat dilihat dari tabel berikut:

\begin{tabular}{|l|l|l|}
\hline \multirow{2}{*}{ Indikator } & \multicolumn{2}{c|}{ Kategori } \\
\cline { 2 - 3 } & Laki-laki & \multicolumn{1}{c|}{ Perempuan } \\
\hline $\begin{array}{l}\text { Pemahaman } \\
\text { masalah }\end{array}$ & Tinggi & Sedang \\
\hline Perencanaan & Tinggi & Sedang \\
\hline $\begin{array}{l}\text { Pelaksanaan } \\
\text { rencana }\end{array}$ & Sedang & Tinggi \\
\hline $\begin{array}{l}\text { Penarikan } \\
\text { kesimpulan }\end{array}$ & Tinggi & Sedang \\
\hline
\end{tabular}

Tabel 4. Kategori rata-rata kemampuan siswa laki-laki dan perempuan berdasarkan indicator kemampuan penyelesaian soal cerita matematika.

Aminah dan Kiki Riska Ayu Kurniawati dalam penelitiannya yang berjudul Analisis Kesulitan Siswa dalam Menyelesaikan Soal Cerita menemukan hasil bahwa kesulitan siswa perempuan dalam menyelesaikan soal cerita yaitu 
dalam hal memahami konsep, menentukan operasi pengerjaan, serta tidak menuliskan kesimpulan akhir, sedangkan kesulitan siswa laki-laki dalam menyelesaikan soal cerita yaitu dalam hal memahami soal sehingga kurang tepat dalam menentukan hasil akhir.

Kristoforus Djawa Djong dalam penelitiannya yang berjudul Proses Kognisi Siswa dalam Menyelesaikan Soal Cerita Topik Pecahan Ditinjau Dari Kemampuan Matematika dan Gender tidak menemukan pengaruh perbedaan gender secara umum dalam proses kognisi siswa. Sedangkan Zubaidah Amir MZ dalam jurnalnya yang berjudul Perspektif Gender dalam Pembelajaran Matematika mengatakan bahwa perbedaan gender tidak hanya berpengaruh pada perbedaan kemampuan dalam matematika saja, akan tetapi juga berpengaruh pada cara memperoleh pengetahuan matematika tersebut. Banyak penelitian yang menemukan tingkat keberhasilan siswa perempuan dalam menyelesaikan permasalahan matematika lebih rendah dari pada tingkat keberhasilan siswa lakilaki. Hal ini berbanding lurus dengan beberapa penelitian yang juga menemukan bahwa tingkat ketertarikan siswa perempuan terhadap soal-soal yang bersifat teoritis lebih rendah dibandingkan ketertarikan siswa laki-laki. Siswa perempuan cenderung lebih tertarik pada soal yang bersifat praktis. Akan tetapi, dilain pihak tidak sedikit juga siswa perempuan berhasil dalam kemampuan penyelesaian soal matematika.

\section{KESIMPULAN}

Berdasarkan hasil dari penelitian ini dan juga beberapa hasil penelitian yang relevan, dapat disimpulkan bahwa secara umum kemampuan penyelesaian soal cerita matematika siswa laki-laki lebih baik dibandingkan siswa perempuan. Dalam hal pemahaman masalah, siswa laki-laki lebih baik dibandingkan siswa perempuan, demikian juga dalam hal perencanaan. Sedangkan dalam pelaksanaan rencana, siswa perempuan lebih baik dibandingkan siswa laki-laki. Dalam hal penarikan kesimpulan, siswa laki-laki juga lebih baik dari siswa perempuan.

Perbedaan kemampuan ini tentu saja berpengaruh pada proses pembelajaran matematika terutama pada lingkungan sekolah. Semoga penelitian ini bermanfaat bagi pihak sekolah, terutama guru matematika, dan pihak lain dalam menentukan strategi dan rencana pembelajaran yang tepat untuk mengatasi perbedaan kemampuan siswa laki-laki dan perempuan ini. Kepada pihak lain yang juga tertarik pada topik penelitian serupa, diharapkan untuk melakukan penelitian lanjutan, agar permasalahan perbedaan kemampuan siswa laki-laki dan perempuan ini, terutama dalam penyelesaian soal cerita dapat diatasi dengan tepat. 
AGENDA : Analisis Gender dan Anak,Vol. 3 (2), 2021, (Desember)

ISSN Print: $\underline{2615-1502}$

ISSN Online: $\underline{2723-3278}$

Tersedia online di

http://ecampus.iainbatusangkar.ac.id/ojs/index.php/agenda

\section{REFERENSI}

Aminah, A., \& Kurniawati, K. R. A. (2018). Analisis Kesulitan Siswa Dalam Menyelesaikan Soal Cerita Matematika Topik Pecahan Ditinjau Dari Gender. JTAM (Jurnal Teori dan Aplikasi Matematika), 2(2), 118122.

As'ari, A.R., dkk. 2017. Buku Guru Matematika SMP/MTs Kelas VII. Buku. Sekolah Elektronik (BSE). Jakarta: Pusat Kurikulum dan Perbukuan.

Ekawati, A., \& Wulandari, S. (2011). Perbedaan jenis kelamin terhadap kemampuan siswa dalam mata Pelajaran matematika (studi kasus sekolah dasar). Jurnal Universitas Borneo Tarakan.

Khasanah, U. (2015). Kesulitan Menyelesaikan Soal Cerita Matematika Pada Siswa SMP.

Kristoforus, D. D. (2015). Proses Kognisi Siswa dalam Menyelesaikan Soal Cerita Topik Pecahan Ditinjau dari Kemampuan Matematika Dan Gender. Wahana: Tridarma Perguruan Tinggi, 64(1), 25-30.

Laili, N. H. (2016). Pengembangan Media Pembelajaran Soal cerita dengan Cerpen Pada Materi Operasi Hitung Campuran untuk Siswa Kelas IV SDN Sumberkerep Tahun Ajaran 2012/2013. SAINTIS, 8(2), 137-150.

Laily, I. F. (2014). Hubungan Kemampuan Membaca Pemahaman Dengan Kemampuan Memahami Soal Cerita Matematika Sekolah Dasar. Eduma:
Mathematics Education Learning and Teaching, 3(1).

Mahfuddin, M., \& Caswita, C. (2021). Analisis Kemampuan Pemecahan Masalah Pada Soal Berbasis High Order Thinking Ditinjau Dari Kemampuan Spasial. Aksioma: Jurnal Program Studi Pendidikan Matematika, 10(3).

Mz, Z. A. (2013). Perspektif gender dalam pembelajaran matematika. Marwah: Jurnal Perempuan, Agama Dan Jender, 12(1), 15-31.

Polya, G. (2004). How to Solve It: A New Aspect Of Mathematical Method (No. 246). Princeton University Press.

Sugiono, D. (2010). Metode penelitian Kuantitatif Kualitatif dan R\&D, penerbit Alfabeta. 